\title{
Migration diplomacy in the Global South: cooperation, coercion and issue linkage in Gaddafi's Libya
}

\section{Gerasimos Tsourapas \\ Department of Political Science and International Studies, University of Birmingham, Birmingham, UK}

\begin{abstract}
Despite a recent resurgence in research on the politics of migration, foreign policy analysts have yet to approach cross-border population mobility as a distinct field of inquiry. Particularly within the Global South, scant work has theorised the interplay between migration and interstate bargaining. This article proposes the framework of migration diplomacy to examine how mobility features in states issue-linkage strategies, in both cooperative and coercive contexts. Drawing on Arabic, French and English primary sources, it empirically demonstrates the salience of its framework through an analysis of Libya's migration diplomacy towards its Arab, African and European neighbours under Muammar Gaddafi.
\end{abstract}

ARTICLE HISTORY

Received 21 March 2017

Accepted 29 June 2017

\section{KEYWORDS}

Middle East

Libya

issue linkage

migration diplomacy

leverage

migration and refugees

Mediterranean

cooperation and coercion

transit migration

\section{Introduction}

'We do not have the word "idiot" written on our foreheads', Turkish President Recep Tayyip Erdogan declared in February 2016. 'We will be patient but we will do what we have to do', he continued, signalling his intention to employ Turkey's position as a transit state for Syrian refugees as leverage against the European Union (EU). 'Don't think that the planes and the buses are there for nothing', he concluded. ${ }^{1}$ While considerable attention has been paid to the domestic political consequences of cross-border mobility, the ways through which migration management features in states' diplomatic conduct remains under-theorised. Despite a wealth of empirical studies identifying states' regulation of migration and asylum practices as foreign policy instruments, the relevant literature has yet to provide a coherent framework for analysing the relationship between diplomacy and cross-border mobility. This is particularly true in the Global South: research on the politics of migration continues to focus predominantly on host states within the Global North, namely the United States, Canada and Western Europe, despite the fact that the majority of migratory flows continue to occur within, and across, developing countries. How does migration feature in the conduct of states' diplomacy in the Global South?

This article paves the way for a major new direction in the study of the politics of international migration by putting forth two arguments. Firstly, states engage in migration diplomacy, namely the use of diplomatic tools, processes and procedures to manage cross-border 
population mobility, including both the strategic use of migration flows as a means to obtain other aims, and the use of diplomatic methods to achieve goals related to migration. Secondly, states within the Global South develop manifold diplomatic strategies in managing diverse migration flows via issue linkage, by engaging in both cooperative and coercive migration diplomacy. Although the line between the two types is frequently blurred, cooperative migration diplomacy is predicated upon interstate bargaining explicitly aiming for mutually beneficial arrangements in the absence of aggression. On the other hand, a state may pursue coercive migration diplomacy if it resorts to violence or the threat of force, or if it adopts a unilateral approach to interstate bargaining.

The article draws upon an extreme case of a Global South state, namely Libya under Muammar Gaddafi, who ruled between 1969 and 2011, in order to test its novel theorisation of cooperative and coercive migration diplomacy. The article goes beyond existing research on Libyan policymaking regarding migration, which has conceptualised Libya as a powerful, oil-producing rentier state, as an unequal trade partner of European states and the EU, or as driven by the erratic behaviour of Gaddafi himself. Rather, the article demonstrates how Libyan politics on population mobility are best understood through the framework of cooperative and coercive migration diplomacy, both of which were employed by Libya in its bargaining with neighbouring states: Gaddafi's strategy towards Arab states focused on securing mainly foreign policy concessions, while his strategy vis-à-vis the EU and individual member states expanded to also include material gains.

Overall, the article makes two contributions: firstly, it provides a comprehensive analysis of Libyan migration politics during the 40 -year rule of Colonel Gaddafi that ties both regional and international politics into a coherent analytical framework. It thereby contributes to work on Middle East states' foreign policy, and enriches the empirical literature on the interplay between migration and diplomacy through an under-examined case within the Global South. Secondly, it develops the concepts of cooperative and coercive migration diplomacy as a novel object of study and research, which furthers the theorisation on issue-linkage and cross-border mobility politics from a foreign policy analysis perspective.

In terms of its structure, the article initially identifies a number of works that empirically examine migration policy as an instrument of diplomacy but have yet to propose a coherent theoretical framework with regard to issue-linkage strategies, or with a focus on the Global South. In response, it develops the concept of migration diplomacy, and proceeds to examine how issue linkage features in states' cooperative and coercive migration diplomacy. It fleshes out its approach empirically through the extreme case of Libya: during the Cold War, Libyan migration diplomacy sought foreign policy gains from Arab sending states; in the post-1990 period, it reoriented towards gaining primarily material concessions from the EU and individual European member states, as well as supporting Gaddafi's vision of a "united" Africa. The article concludes with a discussion on how its findings are significant beyond the Libyan case, as well as how future research may advance its theoretical framework.

\section{The international politics of migration in the Global South}

Theories of international relations, as well as the subfield of research into the politics of migration, have approached labour migration in various ways, and have only recently attempted to theorise on the role of the state. ${ }^{2}$ Traditionally, within the realist and neorealist tradition, international migration would be considered a "low" rather than a "high" politics 
issue and would not factor into analyses of foreign or national security policy. Notable exceptions, such as research by Zolberg, as well as Reiner and Russell, on the political dimension of mobility, ${ }^{3}$ tended to focus specifically on immigration and border controls. With the possible exception of historical work on global migration politics between the two Cold War camps, ${ }^{4}$ a key characteristic of this scholarship is also a tendency 'to focus on the consequences of immigration in wealthy, migrant-receiving societies, and to ignore the causes and consequences of migration in countries of origin within the Global South. ${ }^{5}$ For structuralist scholars of world-systems theory, the divide between sending, transit and host states matters even less, as international migration flows result from economic interests operating in the domestic and international systems. ${ }^{6}$

This is not to argue that the literature has not identified the importance of migration or asylum policies in states' diplomatic practices. A growing number of scholars examine how countries of destination link their immigration, asylum and refugee policies to their foreign policy priorities, albeit primarily within the Organisation for Economic Co-operation and Development (OECD) or the EU context. ${ }^{7}$ An emerging literature, building on a broadly constructivist framework, has developed the foreign policy field of 'diaspora politics.' 8 While including numerous Global South states, such research does not typically examine interstate relations, traditionally focusing on diasporic actors as the unit of analysis. A small group of scholars have recently shifted their attention to sending states and country-of-origin politics, ${ }^{9}$ but they similarly examine state-diaspora relations, rather than interstate diplomacy. At the same time, the research agenda on 'emigration states' further reifies an analytic categorisation between policies developed by countries of immigration and emigration. This prevents an accurate examination of policies developed by states, particularly within the Global South, which regulate more than one type of cross-border mobility. Jordan, Egypt and Turkey, for instance, develop complex, multi-tier policies on emigration, immigration and transit migration, as well as diaspora and refugee issues that cannot adequately be analysed via a unitary perspective based on these policies' target actors. ${ }^{10}$

Expanding beyond the literature on migration politics, two main groups of foreign policy analysts allow for a closer examination of the interplay between diplomacy and cross-border mobility that may be expanded to the Global South: on the one hand, building on liberal trade theory and neo-functionalism, scholars of complex interdependence argue that growing interconnectedness, through international migration or other forms, contributes to cooperation and stability. ${ }^{11} \mathrm{~A}$ line of liberal institutionalist thinkers argue that free movement of people, and rising levels of cooperation and interdependence, would reduce the need for coercion in international relations. ${ }^{12}$ One notable example would be the creation of the European Coal and Steel Community; the 1951 Treaty of Paris ensconced the right to free movement of labour within the signatory states, ostensibly as a way of enhancing interstate cooperation in the aftermath of World War II. ${ }^{13}$ While similar debates have been identified in the Global South, the extent to which they have contributed to interstate cooperation and the absence of conflict has yet to be examined.

On the other hand, a line of security studies scholars argue that migration might contribute to coercive, rather than cooperative, interstate relations. In terms of interstate relations, Greenhill has analysed states' abilities to engender targeted migration and refugee 'crises' in order to shape decision-making processes within the targeted host state. ${ }^{14}$ Her framework suggests that elites in conflict-prone countries are willing to exploit threats to launch migration waves vis-à-vis liberal regimes in order to coerce them into concessions because of costs 
imposed on their civilian populations. But Greenhill's argumentation does not extend into illiberal regimes, frequently found within the Global South, which would be expected to be less prone to such coercion. Similarly, a number of scholars have empirically highlighted the importance of migration in non-OECD states' foreign policies within historical case studies, but without treating it as a separate line of theoretical inquiry. ${ }^{15}$ Focusing on Jordan, for instance, Brand argues that 'it may make sense to think of ... Jordanian expatriate labor in Kuwait' as a form of 'economic statecraft', but she does not carry this argument any further. ${ }^{16}$ The following section aims to synthesise states' cooperative and coercive diplomatic practices on matters of cross-border mobility in a novel framework of migration diplomacy and issue linkage.

\section{Theorising cooperative and coercive migration diplomacy}

This article aims to build on aforementioned work in conceptualising how cross-border population mobility affects the conduct of states' diplomacy, and puts forth two research hypotheses. Firstly, it hypothesises that migratory flows across national borders constitute an object of interstate diplomacy, affecting states' diplomatic relations with other actors in the international system, or migration diplomacy. While this phenomenon is not new, as mentioned earlier, it has yet to constitute a separate field of inquiry within international relations, thereby restricting theorisation on the importance of cross-border mobility for interstate relations. For the purposes of this analysis, migration diplomacy is defined as the use of diplomatic tools, processes and procedures to manage cross-border population mobility, including both the strategic use of migration flows as a means to obtain other aims, and the use of diplomatic methods to achieve goals related to migration. ${ }^{17}$ Immigration laws, bilateral or multilateral readmission agreements, policies of secondment and diaspora outreach, or deportation regulations typically constitute notable tools of migration diplomacy.

How does migration diplomacy feature in the strategies of states in the Global South? The article's second hypothesis is that states in the Global South employ cooperative and coercive migration diplomacy in their management of cross-border mobility. This article introduces existing work from the literature on issue-linkage processes - that is, simultaneous negotiations on two or more issues aiming for joint settlement $-{ }^{18}$ in order to comprehend how it may be employed in cooperative or coercive interstate bargaining within the Global South. With regard to the literature on the politics of migration, the focus on issue-linkage migration diplomacy in the Global South allows for a bypassing of the artificial categorisation between countries of origin and destination. With regard to the literature on issue linkage, the article shifts the scholarly discussion away from the expectation that linkage constitutes a mechanism mainly for stronger states within the Global North to impose their will upon weaker states. ${ }^{19}$ Existing analyses of linkage or 'suasion games', identifying hegemonic powers' strategies over other actors in the international system, ${ }^{20}$ do not usually examine weaker states within the Global South as engaging in issue linkage, save in discussions on military conflict or counterinsurgency. ${ }^{21}$ This article highlights how, in the absence of other forms of leverage typically at the disposal of stronger, developed countries, Global South states are able to use migration diplomacy as issue linkage.

I define coercive migration diplomacy as the threat or act by a state, or coalition of states, to affect either migration flows to/from a target state or its migrant stock as a punishment, unless 
the target state acquiesces to an articulated political or economic demand. This is reminiscent of the use of positive sanctions in international relations. ${ }^{22}$ One recent example of such a process would be the negotiations around the February 2016 'Jordan Compact'. As a host state of thousands of Syrian refugees, fleeing their homeland since 2011, Jordan was able to negotiate major economic benefits from various international actors. In return, Jordan pledged to continue hosting and providing employment opportunities for Syrian refugees within its borders. ${ }^{23}$ Similarly, I define cooperative migration diplomacy as the promise or act by a state, or coalition of states, to affect either migration flows to/from a target state or its migrant stock as a reward, provided that the target state acquiesces to an articulated political or economic demand. This is reminiscent of the use of negative sanctions in international relations. ${ }^{24}$ In November 2015, when Turkey shot down a Russian Su-24M military aircraft, President Putin responded by unilaterally suspending visa-free travel for Turkish citizens seeking employment in Russia. A few years back, in 1999, Japan threatened to ban all migrant remittances sent to North Korea (estimated at $\$ 600$ million to $\$ 1$ billion USD, annually) if Pyongyang did not abandon its plans to test-fire long-range ballistic missiles. ${ }^{25}$ Although the line between the two types is frequently blurred, cooperative migration diplomacy is predicated upon interstate bargaining explicitly aiming for mutually beneficial arrangements in the absence of aggression. On the other hand, a state may pursue coercive migration diplomacy if it resorts to violence or the threat of force, or if it is driven by a unilateral approach to interstate bargaining. The article proceeds to tests its two main hypotheses namely that cross-border mobility constitute an object of interstate diplomacy, and that states aim to affect migration flows and/or migrant stocks through coercive and cooperative issue-linkage strategies in accordance with articulated political or economic demands.

\section{Libyan migration diplomacy - methodology and case selection}

In testing these two hypotheses, the article employs a case study, focusing on Libya under Colonel Gaddafi (1969 to 2011) through within-case analysis. Libya constitutes an 'extreme' case, an unusual example of a Global South state consistently employing both coercive and cooperative migration diplomacy throughout the Gaddafi period. It is chosen for exploratory purposes with regard to the causal mechanisms proposed, for it allows for a maximisation of variance on strategies issue-linkage strategies, both on the coercive and cooperative ends. Extreme cases are also able to provide in-depth insights and rich information. ${ }^{26}$ In that respect, it is similar to countries such as Jordan or Turkey. Libya is distinguished from Jordan due to its position in the transit migration route to Europe, and also differs from Turkey given its historically focal position as destination of both Arab and African labour migration. Both aspects raise Libya's profile as critical in testing the article's theory on multiple modes of issue-linkage migration diplomacy.

While a number of scholars have produced work on Libyan migration politics, particularly in the last decade, research continues to be rather fragmented: Libya is analysed either with regard solely to intra-Arab migration, ${ }^{27}$ or with regard to its relations to the Global North. ${ }^{28}$ At the same time, the majority of works treat Libyan policy under Gaddafi as ad hoc and contradictory, ${ }^{29}$ 'ebullient' or 'unpredictable, ${ }^{\prime 30}$ or operating under 'controlled chaos., ${ }^{31}$ While this article does not intend to discount the personality of Colonel Gaddafi in shaping Libyan politics, it also seeks to move beyond broadly Orientalist interpretations of Arab states' policymaking processes as incomprehensible or illogical. Instead, it aims to provide a first 
synthesis of Libyan migration politics in the 1969-2011 period under a coherent theoretical framework.

While a long debate continues as to the merits of the case-study approach to social sciences research, ${ }^{32}$ there is a broad understanding that it is particularly apt with regard to the exploration of new concepts and allows the fine-tuning of the early stages of a research agenda, as is the goal here. ${ }^{33}$ With regard to data collection, it needs to be noted that work in authoritarian contexts presents unique challenges, particularly in the Middle East where migration is traditionally considered a security issue for Arab elites. ${ }^{34}$ At the same time, research on migration politics suffers from a lack of easily accessible and reliable statistical data. ${ }^{35}$ To overcome these issues, this article relies upon a meticulous collection of the coverage of regional labour migration issues across three main Egyptian newspapers (al-Ahram, al-Akhbar, al-Gumhuriya). In an attempt to fill in gaps and substantiate Egyptian reporting, I also draw on Libyan media sources as well as the international press. Finally, for the purposes of triangulation, I employ semi-structured expert and elite interviews conducted in Cairo $(n=31)$ between July 2013 and June 2014 .

\section{Libyan migration diplomacy in the Arab world}

This section examines Libyan migration diplomacy towards its Arab counterparts, particularly Egypt and Tunisia, between 1969 and 2011, and identifies strategies of issue linkage with regard to both interstate cooperation and coercion. It is worth noting that Libya quickly became a prime destination of migrant labour in the Middle East once oil was discovered in 1957. In the early 1950s, the newly independent kingdom, having emerged following the collapse of Italy's colonial endeavours in World War II, suffered from a lack of trained labour: indicatively, the 1954 census identified $81 \%$ of the population as illiterate. Ten years later, in 1964, the percentage of Libyans who had completed primary education did not exceed $5.2 \% .^{36}$ Not unlike the experience of newly independent Arab states of the Gulf, Libyan development necessarily relied upon the influx of skilled and unskilled migrant labour. ${ }^{37}$

Egyptian and Tunisian migrant labour enjoyed particularly favourable access to the Libyan economy in the early years of Colonel Muammar Gaddafi's rule, who had ousted King Idris, the country's first ruler post-independence, through a bloodless coup d'état in 1969. In these early years of rule, Libya's regional migration diplomacy was employed as an instrument of closer cooperation with neighbouring Arab states. While the facilitation of immigration was economically beneficial to the Libyan state, the distinct preference for Arab workers was a politically motivated decision. A 1971 agreement between Tunisia and Libya facilitated Tunisian migration, while Egyptians were allowed entrance into the country merely with an identity card. They quickly became Libya's main migrant labour community, occupying positions across multiple sectors of the economy (see Table 1). While available statistics on intraArab migration frequently do not give an accurate depiction of migrant stocks or flows, conservative estimates put the number of Egyptians working in Libya at 229,500 in 1975 (it would rise to 250,000 by 1980 ).

Libyan migration diplomacy explicitly aimed at linking cooperation on issues of cross-border mobility with closer political integration. As Gaddafi prepared for the creation of a federation with Syria and Egypt - the Federal Arab Republic - Libya abolished entry visa requirements for Egyptian migrants in 1971. A similar agreement was signed with Tunisia in the same year, as Gaddafi sought to unify Libya with the remaining North African Arab 
Table 1. Employment by economic sector and nationality, 1975.

\begin{tabular}{|c|c|c|c|c|c|c|}
\hline \multirow[b]{2}{*}{ Sector } & \multicolumn{2}{|c|}{ Libyans } & \multicolumn{2}{|c|}{ Non-nationals } & \multirow[b]{2}{*}{ Total } & \multirow{2}{*}{$\begin{array}{c}\text { Libyans' } \\
\text { share of all } \\
\text { employment }\end{array}$} \\
\hline & Number & Percentage & Number & Percentage & & \\
\hline Agriculture & 115,500 & 25.4 & 17,600 & 7.9 & 133,100 & 86.8 \\
\hline Mining, quarrying and petroleum & 12,100 & 2.7 & 5,500 & 2.5 & 17,600 & 68.8 \\
\hline Manufacturing & 19,100 & 4.2 & 13,800 & 6.2 & 32,900 & 58.1 \\
\hline Electricity, gas and water & 9400 & 2.1 & 3600 & 1.6 & 13,000 & 72.3 \\
\hline Construction & 34,600 & 7.6 & 118,000 & 53.0 & 152,600 & 22.7 \\
\hline Trade, restaurants and hotels & 40,800 & 9.0 & 7700 & 3.5 & 48,500 & 84.1 \\
\hline Transport, storage and communication & 47,200 & 10.4 & 6200 & 2.8 & 53,400 & 88.4 \\
\hline Finance, insurance and real estate & 6100 & 1.3 & 1600 & 0.7 & 7700 & 79.2 \\
\hline $\begin{array}{l}\text { Public administration, education, health } \\
\text { and other }\end{array}$ & 169,600 & 37.3 & 48,700 & 21.8 & 218,300 & 77.7 \\
\hline Total & 454,400 & 100.0 & 222,700 & 100.0 & 677,100 & 67.1 \\
\hline
\end{tabular}

Data source: J. S. Birks and C. A. Sinclair, International Migration and Development in the Arab Region (Geneva: International Labor Organization, 1980), p. 162.

states - Tunisia, Morocco and Algeria. ${ }^{38}$ Delighted at this inflow of Egyptian and Tunisian workers, Gaddafi tied cooperation on cross-border mobility with his broader, pan-Arab vision of a united Arab world. Styling himself after Egyptian President Gamal Abdel Nasser, Gaddafi soon turned into 'the self-appointed guardian of Nasser's legacy nurturing the notion of Arab nationalism and unity. ${ }^{39}$ It is unsurprising that Gaddafi would frequently argue that unrestricted movement of labour in the Middle East constituted a key step in the road to 'the unification of all Arabic-speaking people.40

However, Libya's bilateral relations with both Egypt and Tunisia quickly went sour. The rise to power of Egyptian President Anwar al-Sadat led to a heightening of tensions between the two states. For Gaddafi, Sadat had abandoned the pan-Arab vision espoused by the first Egyptian President, Gamal Abdel Nasser, who had passed away unexpectedly in 1970. Egypt's management of the 1973 Arab-Israeli War was particularly criticised by Gaddafi, who failed to understand the reasons behind the Egyptian refusal to deal a devastating blow against Israel. The defection of two majors in the Revolutionary Command Council of Libya to Egypt ('Abd al-Mun'im al-Huni and 'Umar'Abdallah al-Muhayshi) was also humiliating for the Libyan leader. Gaddafi became, in turn, eager to provide shelter to political dissenters who had fled Egypt, including Hikmat Abu Zayd, who had been Egypt's first female minister in the early 1960s. She relocated to Libya in 1974 and, from her position at the University of Tripoli, frequently criticised Sadat's policies. Partly in an effort to counterbalance Gaddafi, Sadat pursued a policy of rapprochement with Sudanese President Gaafar al-Nimeiry, with whom he shared a distrust of Libyan regional ambitions. A breaking point was reached in April 1974, when Sadat blamed a failed assassination attempt against him on the Libyan regime. Egypt withdrew from the negotiations on the creation of the Federal Arab Republic, accusing Qaddafi of being mentally ill, or a 'lunatic'41

Libyan migration diplomacy, in turn, shifted to coercion, pursuing an issue-linkage strategy that aimed to harness Arab sending states' foreign policy into submission. The failure of Gaddafi's plan to create a unified state with Tunisia, the Arab Islamic Republic, resulted in a concerted backlash against Tunisian workers in Libya, as thousands of Tunisians would be expelled on random occasions, such as the deportation of 5000 Tunisians in $1976 .{ }^{42}$ By late April 1974, Gaddafi ordered the deportation of hundreds of Egyptian migrants, many of whom were tortured before being driven to the Egypt-Libya border. For those Egyptian 
migrants who remained in the country, daily life became much harder, as they faced discrimination and abuse by Libyan military and security services.

Egyptian migration diplomacy was adjusted accordingly, as Sadat legally forbade civil servants employed by the Egyptian state to travel to Libya regardless of reason, targeting the Libyan economy's reliance on Egyptian professionals on secondment. Gaddafi embarked on a second round of deportations in April 1975, as one Egyptian migrant, Mufrih Nasr Isma'il, a migrant from Fayyoum, died in Derna, while under police custody. Egyptian parliamentarians and the Arab Socialist Union, the main political party at the time, put forth proposals for the immediate withdrawal of the entire Egyptian community in Libya, estimated to be 300,000 strong. The Middle East News Agency would report instances of 'barbarous' torture of Egyptian migrants at the hands of the Libyan security forces, which included beatings with 'sticks, whips, and pipes' as well as sleep deprivation. ${ }^{43}$

Interestingly, Egypt never considered this issue a human rights violation. Instead, the Egyptian regime approached it as a political issue that was part and parcel of Libyan migration diplomacy. This was, firstly, evident by Sadat's emphasis on countermeasures, such as the restriction of emigration outlined above. At the same time, in the midst of the April 1975 migration crisis, Sadat visited Saudi Arabia; Egyptian news agencies reported that the Saudi state'was ready to absorb all the Egyptian migrants working in Libya who now wish to leave', in an attempt to neutralise Gaddafi's issue-linkage strategy. Above all, the Egyptian regime aimed at projecting confidence in the face of Libyan coercion, ensuring that Egyptian newspapers underlined that Saudi requests for Egyptian labour 'exceed the number of Egyptian workers in Libya'.44

A similar strategy was employed almost a year later, in March 1976, when Libyan authorities reneged on the policy of allowing entry to Egyptians carrying identity cards, and deported over 3000 workers. The Matrouh governorate in Egypt, close to the Libyan border, declared a state of emergency given that deportees were unceremoniously abandoned at the border stations by Libyan authorities. Sayyid Fahmi, the Egyptian Minister of Interior, had to dispatch trains and buses to pick up the deportees. Again, Libyan migration diplomacy produced a number of casualties: at least one migrant worker died on 20 March, while Yunis 'Abd al-'Al was completely paralysed and left unable to speak as a result of head injuries. ${ }^{45}$ A variety of reports were also circulated that male Egyptian migrants were recruited into the Libyan armed forces against their will, while others were tortured into relinquishing their Egyptian citizenship in favour of a Libyan one. Abuse continued intermittently until early October 1976, when approximately 2500 Egyptians were arrested in Derna, in Eastern Libya. The migrants were tortured before being handed over to border authorities at the Egyptian border station in Marsa Matrouh. Sadat continued to view Libyan migration diplomacy as a strategy, with Egyptians treated as bargaining chips in bilateral relations: when interviewed on the humanitarian crisis that had been created, Sadat mentioned that he did not 'take the situation so seriously. We are ready to absorb our workers; they can find work here, or in other Arab countries.'46

Gaddafi's issue-linkage strategy in his use of coercive migration diplomacy became evident in January 1977, when Egypt, Syria, and Sudan announced the creation of a Unified Political Command. This would involve, inter alia, the build-up of military forces close to the Egyptian-Libyan border. Following the inspection of these forces by the Egyptian Minister of War on 27-28 March 1977, Gaddafi issued a declaration stating that 'Sadat, in his behaviour, intends to oblige $u^{\prime}{ }^{\prime 7}$ to impose countermeasures on the Egyptian migrant population. The 
Libyan state ceased issuing new migrant visas to Egyptians, and proceeded with mass deportations of existing migrants, regardless of legal status. The governor of Marsa Matrouh prepared to receive some 10,000 Egyptian deportees per day, all arriving in open-backed trucks that had been filled to capacity. Could such measures have an economic, rather than a political or diplomatic, rationale? Perhaps, it could be argued, Libya had been trying to nationalise its workforce by ridding itself of migrant labour. This is inconsistent with the actions of 'Abd al-Salam Jalloud, the Libyan Prime Minister who, in May 1977, toured Eastern Europe in search of replacement migrant labour.

Sporadic incidents with regard to Arab migrant labour occurred in later years, as the state of bilateral relations ebbed and flowed. In 1985, the Libyan state radio, the Voice of the Great Arab Homeland, declared that Egypt and other Arab states had ceased supporting the creation of a unified Arab state, which meant that Arab workers in Libya would be considered foreigners. Gaddafi denounced Arab elites as 'monkeys' that had 'sold themselves' to Washington. Under this logic, Arab workers were deemed to be complicit and measures were taken for deportation. ${ }^{48}$ In August 1985, over 5000 Tunisians had their belongings confiscated and were given the choice to either adopt the 'Arab nationality' or face expulsion, following Tunisian President Habib Bourghuiba's visit to Washington, DC. Tunisian diplomats went on record as stating that these measures 'were intended to put pressure on Tunis to cut ties with the West.'.49

Occurring at the same time, the expulsion of Egyptian workers was also part of a broader confrontation between the two states. Bilateral tensions were centred primarily on Egyptians troops' mobilisation along the border between the two states, as well as the Libyan hijacking of an Egyptian airliner, both in 1985. There were estimates that 20,000 Egyptians were deported in August and September 1985, while other reports put the number at 100,000.50 A similar fate awaited Tunisian migrant labour in Libya, as about 20,000 workers were also deported on similar grounds. The Libyan Ministry of Planning estimates verify this tumultuous change in migrant labour numbers (Table 2).

Finally, beyond employing migration in bilateral relations with Arab states, Gaddafi also attempted issue linkage with regard to the Israeli-Palestinian dispute. In September 1994, he declared his opposition to the Oslo peace accords process between Israel and the Palestinian Liberalisation Organization (PLO), arguing that 'what is happening in the name of peace is nothing but a surrender and a recognition of the existence of Israel at the expense of Palestinians. ${ }^{11}$ Deportations of Palestinians began in mid-1995, as approximately 1000

Table 2. Sectoral distribution of foreign labour in Libya, 1970-1990.

\begin{tabular}{|c|c|c|c|c|c|c|c|c|c|c|}
\hline \multirow[b]{2}{*}{ Sector } & \multicolumn{5}{|c|}{ Number of workers (in thousands) } & \multicolumn{5}{|c|}{ Percentage of total } \\
\hline & 1973 & 1978 & 1982 & 1985 & 1990 & 1973 & 1978 & 1982 & 1985 & 1990 \\
\hline Agriculture, forestry and fishing & 14 & 29 & 29.2 & 25 & 10.3 & 11.8 & 11.5 & 8.8 & 12.8 & 7.4 \\
\hline Extraction of oil and natural gas & 3 & 2 & 2.7 & 2 & 2.5 & 2.5 & 0.8 & 0.8 & 1.1 & 1.7 \\
\hline Mining and manufacturing & 11 & 22 & 39.4 & 17 & 11.8 & 9.3 & 8.7 & 12 & 8.7 & 8.4 \\
\hline Electricity and water & 1 & 5 & 4.5 & 3 & 1.4 & 0.9 & 2 & 1.4 & 1.5 & 1 \\
\hline Construction & 58 & 122 & 170.5 & 107 & 89.8 & 49.2 & 48.4 & 51.7 & 54.9 & 64.6 \\
\hline Wholesale and retail trade & 4 & 5 & 1.5 & 1 & 0.5 & 3.4 & 2 & 0.5 & 0.5 & 0.4 \\
\hline Transport and communication & 2 & 8 & 11.6 & 4 & 2 & 1.7 & 3.2 & 3.5 & 2.1 & 1.4 \\
\hline Finance, insurance and banking & 1 & 1 & 1.1 & 1 & 0.1 & 0.9 & 0.4 & 0.3 & 0.5 & 0.1 \\
\hline Administrative and social services & 24 & 58 & 69.1 & 35 & 20.8 & 20.3 & 23 & 21 & 17.9 & 15 \\
\hline Total & 118 & 252 & 329.6 & 195 & 139.2 & 100 & 100 & 100 & 100 & 100 \\
\hline
\end{tabular}

Data sources: Libyan Ministry of Planning, Three-Year Economic Development Plan, 1973-1975, and Five-Year Economic and Social Transformation Plans of 1976-1980, 1981-1985; and Libyan Central Bank, Economic and Social Indicators. 
workers were abandoned on the Egyptian borders, with further threats by Gaddafi to deport some 30,000 Palestinians (that never materialised), as an instrument of pressure to the PLO:

This is not a return and not an expulsion. This is pushing the Palestinians, in accordance with their wishes or not, to return to Palestine ... This is the first point we want to correct and show that there is a great deception, disregard of the Arabs and misdirection of the international public opinion concerning what is happening now to the Palestinians. ${ }^{52}$

\section{Libyan migration diplomacy towards Africa and Europe}

Libya under Gaddafi did not employ migration diplomacy merely in its bilateral workings with the Arab world, but also employed it with regard to its relations with sub-Saharan African countries, as well as the EU and individual EU member states, most notably Italy, particularly given Libya's increasing regional and international isolation. This phenomenon intensified once Gaddafi abandoned his interest in Arab unity in favour of pan-Africanism: once the end of the Cold War marked the end of superpower aid to African states, Gaddafi identified a new opportunity for Libyan leadership. This section examines how Libyan migration diplomacy towards African states aimed at projecting Gaddafi's role in constructing the federal 'United States of Africa', as he repeatedly announced, 'to transform the continent into a single nation-state ruled by a single government. ${ }^{53}$ With regard to Europe, this section details Gaddafi's primarily coercive migration diplomacy, as he tried to employ Libya's status as a transit state of irregular migration for military, political and economic purposes. ${ }^{54}$

Reminiscent of Gaddafi's strategy vis-à-vis Arab elites, the country's migration diplomacy towards African sending states coincided with Libya's wish to pursue closer ties of cooperation. From the early 1990 s onwards, as Gaddafi became less interested in pan-Arabism and, instead, sought to spearhead closer ties among African states under pan-Africanism, he utilised cooperative migration diplomacy: a 1990 integration charter with Sudan, a 1994 agreement with Chad, and the 1998 creation of the Community of Sahel-Saharan States (CENSAD) contained numerous objectives regarding the free movement of people. Gradually, Gaddafi employed Libya's position as a host state for African labour in order to further his diplomatic openings towards African states. While immigration had distinct economic advantages for the Libyan economy at the time, 'the regime sought a leadership role in the international arena to counter its increasing isolation from Arab countries and the West'.55

Yet Libya gradually lost its appeal as a host state for African labour;'each period of interstate tension is followed by expulsions, whose victims have been the Tunisians, the Egyptians, and Palestinians', Pliez described. 'But it is now increasingly those from sub-Saharan countries. ${ }^{56}$ The regime deliberately stoked anti-migrant racism, leading to mass anti-African riots in 2000. These resulted in the death of 130 migrants and the subsequent expulsion of thousands of African migrants. Gaddafi's attempts to not upset African states or his claims to pan-Africanism, while also abandoning the responsibility to provide employment for an ever-increasing number of African migrants, led the regime to reassess its position on Libyan migration diplomacy. Libya, from the early 2000 s onwards, adopted the position of a transit, rather than host, state for sub-Saharan and West African labour.

Following this shift, Libyan migration diplomacy would target the EU and individual member states, as Gaddafi's issue-linkage strategy initially aimed at the lifting of economic sanctions, imposed upon Libya since 1986. He tellingly declared, in June 2002, that 'no North African state wishes to guard the gates of Europe for free, as our region is invaded by 
sub-Saharan migrants. ${ }^{57}$ Gaddafi's migration diplomacy entailed the gradual release of irregular migration into Italy, in an attempt that Greenhill has characterised as 'capacity-swamping', aiming to coerce the target state into submission. In late 2004, Libya declared that it would 'no longer act as Europe's coast guard', as Gaddafi demanded the lifting of European economic sanctions against Libya. ${ }^{58}$ This was preceded by months of putting pressure on European states, particularly Italy, which had received almost 10,000 African migrants to the island of Lampedusa, via the Libyan route - or, as it has been termed since, the Central Mediterranean route. In mid-2003, shortly before Italy was due to take the helm of the EU Council presidency, it launched a campaign to convince other EU member states of the need to remove the arms embargo against Libya, as weapons were necessary to combat African irregular migration. ${ }^{59}$ Faced with lacklustre European support, Italy went so far as to threaten a unilateral lifting of economic sanctions against Libya. Eventually, Libya's coercive migration diplomacy was successful, and the EU embargo was fully lifted.

A few years later, in 2007-2008, irregular migration through Libya into Italy peaked again at some 37,000 migrants intercepted at its borders, as opposed to 19,000 in 2006. Gaddafi aimed to have Rome offer a formal apology for its colonial brutalities in Italian Libya. On 30 August 2008, Italian Prime Minister Silvio Berlusconi offered a formal apology from Benghazi, as the two leaders signed a friendship and cooperation treaty. Besides an Italian commitment of $\$ 5$ billion towards developing Libyan infrastructure over 20 years, Berlusconi offered a condemnation of Italian colonialism in the region:

'In the name of the Italian people, as head of the government, I feel it my duty to apologise and express my sorrow for what happened many years ago and left a scar on many of your families ${ }^{\prime} 60$

In return, Libya agreed to cooperate with Italy against irregular migration, as stipulated in Article 19 of the treaty. This clearly stated Libya's need to comply with previous agreements and protocols, as well as to allow the 2000-km-long Libyan coast to be protected by Italian patrolled boats, carrying mixed crews. Its land borders were also to be monitored, by a satellite detection system. Joint patrols began in 2009 and, by 2010, the EU declared the project to be a success, reducing irregular migration to a fraction of its former volume (3200 detections in the first seven months of 2009, as opposed to 40,000 detections in 2008), and an overall reduction in border crossings (see Figure 1).

Finally, beyond ensuring the end of the EU embargo and a formal apology for Italy's colonial past, Libya's migration diplomacy under Gaddafi also aimed at purely economic benefits: in an August 2010 EU-Africa Summit in Italy, Gaddafi proposed that he could take the role of guarding Europe's borders, as:

Tomorrow Europe might no longer be European, and even black, as there are millions that want to come in ... We don't know what will happen, what will be the reaction of the white and Christian Europeans faced with this influx of starving and ignorant Africans ... We don't know if Europe will remain an advanced and united continent or if it will be destroyed, as happened with the barbarian invasions. (quoted in The Guardian, August 31, 2010)

Gaddafi's issue-linkage strategy aimed at securing $€ 5$ billion ( $£ 4.1$ billion) a year in order to ensure that Europe would not 'turn black.61 A few years before, during a meeting of the African Union, Qaddafi stated that

We will ask Europe to pay 10 billion euros per year if it really wants to stop migration toward Europe... Europeans who do not want to take the immigrants should either emigrate to American or pay Libya to keep its borders closed. ${ }^{62}$ 


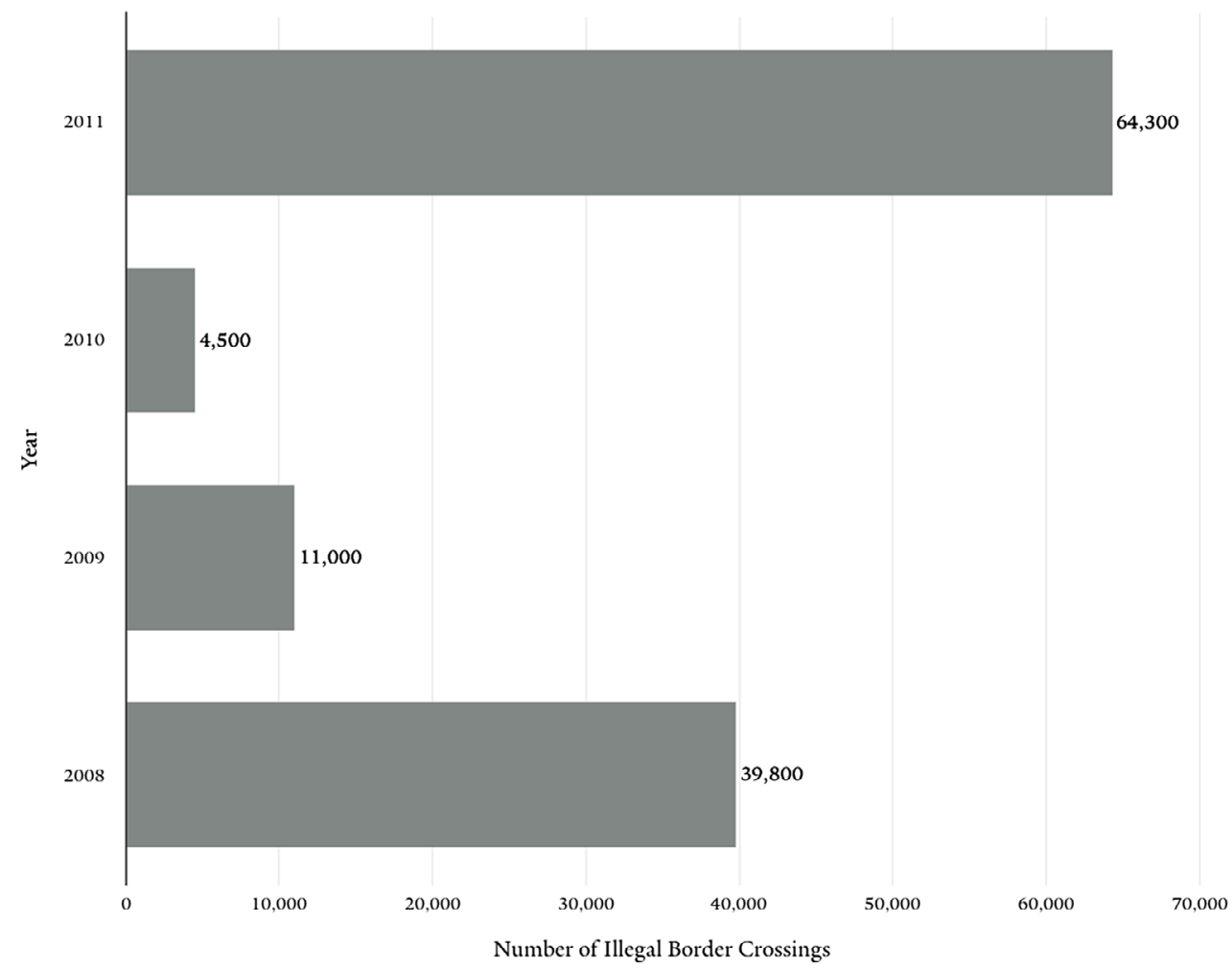

Figure 1. Illegal border crossings on the central Mediterranean route (data from Frontex 2016).

\section{Conclusion}

This article addressed the ways in which cross-border population mobility features in the international relations of Global South states. It has put forth, firstly, the concept of migration diplomacy as a more accurate conceptualisation of states' employment of diplomatic tools, processes and procedures distinctly related to migration. Secondly, it identified how migration diplomacy within the Global South takes the form of issue-linkage strategies of interstate cooperation or coercion. The article demonstrated both types of migration diplomacy through an examination of Libya under Colonel Gaddafi, between 1969 and 2011. Going beyond the limitations of existing approaches, it has identified how Libyan policymaking was driven by issue-linkage strategies with regard to Arab, African and European target states. Libya aimed to gain foreign policy concessions from Arab sending states in the pre1990 period; in the post-1990 period, it aimed to gain various concessions from the EU and individual European member states, as well as support for Gaddafi's vision of a 'united' Africa.

The strategic selection of the Libyan case attempted to address the obstacles of generalisability via a single-case study by allowing the generation and analysis of data needed to provide robust answers to the article's research question, and by providing rich insights into the mechanisms at play. How does the article's theorisation travel beyond the Libyan case? Arguably, both cooperative and coercive migration diplomacy has been traditional to varying 
extents for a number of states within the Global South. Examples of issue-linkage practices within the Arab world, in particular, abound: coercive migration diplomacy was employed by Iraqi President Saddam Hussein against Egypt in 1990, when he ordered the displacement of hundreds of thousands of Egyptian workers from Iraq partly to coerce Egypt into abandoning support for Operation Desert Storm. The same year, Saudi Arabia also pursued coercive migration diplomacy against Yemen, which had refused to denounce the Iraqi invasion of Kuwait in the United Nations Security Council, by deporting some 800,000 Yemeni migrants. ${ }^{63}$ But the Middle East also features instances of cooperative migration diplomacy, such as the organised export of Egyptian professionals for developmental purposes across the Arab world under President Gamal Abdel Nasser. ${ }^{64}$ Beyond the Middle East, the case of Cuba provides instances of both coercive migration diplomacy, taking the form of engineered refugee crises targeted against the United States, ${ }^{65}$ and cooperative migration diplomacy, known as Cuban 'medical internationalism'. Under the auspices of the latter, thousands of Cuban doctors, nurses and other medical staff are dispatched in other Latin American and African states as a form of 'soft power'.66

Overall, the article has argued for the importance of the concept of migration diplomacy in highlighting the importance of population mobility for interstate relations in the Global South. It has also introduced issue linkage as a framework for comprehending states' increasingly common coercive and cooperative strategies in migration management. Beyond theoretical relevance, the article aims to shed light on current policy matters, such as the 2016 EU-Turkey agreement, which grants Turkey certain political and economic concessions in return for its management of Syrian refugees - an agreement that Turkey has been threatening to renege upon, again as part of its coercive migration diplomacy. Future research is needed in order to enhance the article's theoretical framework, possibly by examining how states' domestic constrains affect their migration diplomacy strategies, in both the Global South and the Global North. The importance of cross-border population mobility in shaping states' diplomatic practices constitutes a fascinating, albeit under-theorised, field of study.

\section{Disclosure statement}

No potential conflict of interest was reported by the author.

\section{Funding}

This work was supported by the Council for British Research in the Levant [2017/18 Pilot Study Award] and by a BA/Leverhulme Small Research Grant [grant number SG163246].

\section{Acknowledgements}

The author wishes to thank Stefan Wolff and Adam Quinn for their insightful comments on an earlier draft of the manuscript.

\section{Note on Contributor}

Gerasimos Tsourapas is a lecturer in Middle East Politics at the Department of Political Science and International Studies, University of Birmingham. His research interests include emigration 
and diaspora politics in the Global South, and the interplay between population mobility and international relations with regard to forced migration and refugee politics. He is currently leading a British Academy/Leverhulme-funded project on 'The Politics of Forced Migration in the Mediterranean', and a project on 'Migration Diplomacy in the Eastern Mediterranean' funded by the Council for British Research in the Levant. He was previously a Senior Teaching Fellow in International Relations at SOAS, University of London (2015-2016) and a Visiting Fellow at the Center for Migration and Refugee Studies of the American University of Cairo (2013-2014).

\section{Notes}

1. Quoted in The Guardian, "Turkish President Threatens."

2. Hollifield, "Politics of International Migration," 189.

3. Zolberg, "Next Waves"; Weiner and Russell, Demography and National Security.

4. Messina, "From Migrants to Refugees"; Tempo, Americans at the Gate; Oyen, Diplomacy of Migration.

5. Castles, Miller, and De Haas, Age of Migration, 26.

6. Sassen, Mobility of Labor and Capital; cf. Cornelius, Martin, and Hollifield, "Introduction: The Ambivalent Quest."

7. Indicatively: Teitelbaum, "Immigration, Refugees, and Foreign Policy"; Hollifield, Immigrants, Markets, and States; Guiraudon and Lahav, Immigration Policy in Europe; Betts and Loescher, "Refugees in International Relations"; A. Geddes and Scholten, Politics of Migration and Immigration in Europe; Huysmans, "European Union and the Securitization of Migration"; Içcluygu and Aksel, "Two-to-Tango in Migration Diplomacy."

8. Adamson, "Growing Importance of Diaspora Politics"; Koinova, "Four Types of Diaspora Mobilization."

9. Østergaard-Nielsen, International Migration and Sending Countries; Brand, Citizens Abroad; Fitzgerald, Nation of Emigrants; Naujoks, Migration, Citizenship, and Development; Délano and Gamlen, "Comparing and Theorizing State-Diaspora Relations"; Margheritis, Migration Governance Across Regions; Adamson, "Sending States"; Koinova, "Sending States and Diaspora Positionality."

10. Tsourapas, "Why Do States Develop."

11. Keohane and Nye, Power and Interdependence; Keohane and Nye, "Power and Interdependence Revisited."

12. Hansen, Koehler, and Money, Migration, Nation States, and International Cooperation; cf. Hollifield, "Migration and International Relations"; Haas, Beyond the Nation State.

13. Moravcsik, Choice for Europe.

14. Greenhill, Weapons of Mass Migration; Greenhill, "Use of Refugees as Political and Military Weapons."

15. Klotz, "Migration After Apartheid"; Thiollet, "Migration as Diplomacy"; Curley and Wong, Security and Migration in Asia.

16. Brand, Jordan's Inter-Arab Relations, 148.

17. Adamson and Tsourapas, "Migration Diplomacy."

18. Haas, "Why Collaborate?"; Davis, "Linkage Diplomacy."

19. Levitsky and Way, Competitive Authoritarianism.

20. Martin, "Interests, Power, and Multilateralism."

21. Mack, "Why Big Nations Lose Small Wars"; Arreguin-Toft, How the Weak Win Wars; Paul, Asymmetric Conflicts, 20. An exception here is Greenhill's work, which however only ascribes Global South states as coercers in these processes.

22. Baldwin, "The Power of Positive Sanctions."

23. Mellinger and van Berlo, "Jordan Compact."

24. Drezner, The Sanctions Paradox: Economic Statecraft and International Relations. 
25. Miyashita, Limits to Power, 163.

26. Gerring, "Is There a (Viable) Crucial-Case Method?"

27. Paoletti, "Migration and Foreign Policy"; Tsourapas, "Politics of Egyptian Migration to Libya."

28. Paoletti, Migration of Power; Joffé, "Libya and the European Union"; Lutterbeck, "Migrants, Weapons and Oil."

29. Paoletti, "Migration and Foreign Policy," 226-7.

30. Pliez, "De L'immigration Au Transit?"

31. Soliman, "Libyan Foreign Policy," 75.

32. B. Geddes, "Cases You Choose Affect the Answers"; Collier and Mahoney, "Insights and Pitfalls."

33. Van Evera, Methods for Students of Political Science.

34. Tsourapas, "Notes from the Field"; Kapiszewski, Nationals and Expatriates.

35. Fargues, "Fuzzy Lines of International Migration."

36. Tsourapas, "Politics of Egyptian Migration to Libya."

37. Cf. Tsourapas, "Nasser's Educators and Agitators."

38. Natter, "Revolution and Political Transition in Tunisia."

39. Vandewalle, History of Modern Libya, 80.

40. Cooley, Libyan Sandstorm, 101.

41. Rohen, Qaddafi's Libya in World Politics, 111.

42. Gaddafi. The New York Times, March 22, 1976.

43. MENA, April 24, 1975.

44. al-Ahram, April 24, 1975.

45. Akhbar al-Yawm, March 20, 1976.

46. Der Spiegel, March 26, 1976.

47. Tsourapas, "Trump's Strategy on Immigration."

48. Fawat, "Libya: Economic Crisis, Political Expulsions."

49. United Press International, August 9, 1985.

50. The New York Times, August 18, 1985.

51. APS Diplomat Recorder, 1994.

52. Quoted in Paoletti, "Migration and Foreign Policy," 225.

53. Quoted in US Department of State, "Background Note: Libya."

54. For more information on the make-up of these migration flows, see Bredeloup and Pliez, "Libyan Migration Corridor."

55. Paoletti, Migration of Power, 86.

56. Pliez, “Gros Plan," 199.

57. Quoted by Reuters, June 24, 2002.

58. Quoted in Greenhill, Weapons of Mass Migration, 330-1.

59. Associated Press, June 24, 2003.

60. Ronzitti, "Treaty on Friendship, Partnership and Cooperation," 125.

61. Squires, "Gaddafi: Europe Will 'Turn Black."'

62. Quoted in Greenhill, Kelly. Weapons of Mass Displacement, 331.

63. Tsourapas, "Labor Migrants as Political Leverage."

64. Tsourapas, "Nasser's Educators and Agitators."

65. Greenhill, "Engineered Migration and the Use of Refugees."

66. Blue, "Cuban Medical Internationalism"; Tsourapas, "Migration as Soft Power."

\section{Bibliography}

Adamson, Fiona. "The Growing Importance of Diaspora Politics." Current History 115, no. 784 (2016): 291-297.

Adamson, Fiona. "Sending States and the Making of Intra-Diasporic Politics: Turkey and Its Diasporas in Europe." International Migration Review, forthcoming.

Adamson, Fiona, and Gerasimos Tsourapas. "Migration Diplomacy - Investigating the International Politics of Mobility Management," forthcoming. 
Arreguin-Toft, Ivan. How the Weak Win Wars: A Theory of Asymmetric Conflict. Cambridge: Cambridge University Press, 2005.

Baldwin, David A. "The Power of Positive Sanctions." World Politics 24, no. 1 (1971): 19-38.

Betts, Alexander, and Gil Loescher. "Refugees in International Relations." In Refugees in International Relations, edited by Alexander Betts and Gil Loescher, 1-28. Oxford: Oxford University Press, 2011.

Birks, J. S., and C. A. Sinclair. International Migration and Development in the Arab Region. Geneva: International Labour Office, 1980.

Blue, Sarah A. "Cuban Medical Internationalism: Domestic and International Impacts." Journal of Latin American Geography 9, no. 1 (2010): 31-49.

Brand, Laurie A., and Citizens Abroad. Emigration and the State in the Middle East and North Africa. Cambridge: Cambridge University Press, 2006.

Brand, Laurie A. Jordan's Inter-Arab Relations: The Political Economy of Alliance-Making. New York: Columbia University Press, 2013.

Bredeloup, Sylvie, and Olivier Pliez. The Libyan Migration Corridor. Florence: Migration Policy Institute, 2011.

Castles, Stephen, Mark J. Miller, and Hein De Haas. The Age of Migration. 5th ed. New York: Guilford Press, 2014.

Collier, David, and James Mahoney. "Insights and Pitfalls: Selection Bias in Qualitative Research." World Politics 49, no. 1 (1996): 56-91.

Cooley, John K. Libyan Sandstorm. New York: Holt, Rinehart, and Winston, 1982.

Cornelius, Wayne A., Philip L. Martin, and James F. Hollifield. "Introduction: The Ambivalent Quest for Immigration Control." In Controlling Immigration: A Global Perspective, edited by Wayne A. Cornelius, Philip L. Martin and James F. Hollifield, 3-42. Stanford: Stanford University Press, 1994.

Curley, Melissa, and Siu-lun Wong. Security and Migration in Asia: The Dynamics of Securitisation. London and New York: Routledge, 2008.

Davis, Christina L. "Linkage Diplomacy: Economic and Security Bargaining in the Anglo-Japanese Alliance, 1902-23." International Security 33, no. 3 (2009): 143-179.

Délano, Alexandra, and Alan Gamlen. "Comparing and Theorizing State-Diaspora Relations." Political Geography 41 (July 2014): 43-53.

Drezner, Daniel W. The Sanctions Paradox: Economic Statecraft and International Relations. Cambridge: Cambridge University Press, 1999.

Fargues, Philippe. "The Fuzzy Lines of International Migration: A Critical Assessment of Definitions and Estimates in the Arab Countries." June 1. Robert Schuman Centre for Advanced Studies Research Paper No. RSCAS 71, 2014.

Fawat, Ibrahim. "Libya: Economic Crisis, Political Expulsions." AfricAsia 22 (1985): 32-43.

Fitzgerald, David. A Nation of Emigrants: How Mexico Manages Its Migration. Berkeley: University of California Press, 2009.

Geddes, A., and P. Scholten, eds. The Politics of Migration and Immigration in Europe. 2nd ed. London: SAGE Publications, 2016.

Geddes, Barbara. "How the Cases You Choose Affect the Answers You Get: Selection Bias in Comparative Politics." Political Analysis 2, no. 1 (January 1, 1990): 131-150.

Gerring, J. "Is There a (Viable) Crucial-Case Method?" Comparative Political Studies 40, no. 3 (March 1, 2007): 231-253.

Greenhill, Kelly M. “Engineered Migration and the Use of Refugees as Political Weapons: A Case Study of the 1994 Cuban Balseros Crisis." International Migration 40, no. 4 (2002): 39-74.

Greenhill, Kelly M. "The Use of Refugees as Political and Military Weapons in the Kosovo Conflict." In Yugoslavia Unraveled: Sovereignty, Self-Determination, Intervention, edited by Raju G. C. Thomas, 205-242. Lanham: Lexington Books, 2003.

Greenhill, Kelly M. Weapons of Mass Migration - Forced Displacement, Coercion, and Foreign Policy. Ithaca: Cornell University Press, 2010.

The Guardian. 2016. "Turkish President Threatens to Send Millions of Syrian Refugees to EU." The Guardian, February 12, sec. World news. https://www.theguardian.com/world/2016/feb/12/turkishpresident-threatens-to-send-millions-of-syrian-refugees-to-eu. 
Guiraudon, Virginie, and Gallya Lahav. Immigration Policy in Europe: The Politics of Control. London: Taylor \& Francis, 2013. https://books.google.co.uk/books?id=gWjaAAAAQBAJ.

Haas, Ernst B. "Why Collaborate? Issue-Linkage and International Regimes." World Politics 32, no. 3 (1980): 357-405.

Haas, Ernst B. Beyond the Nation State: Functionalism and International Organization. Colchester:ECPR Press, 2008.

Hansen, Randall, Jobst Koehler, and Jeannette Money. Migration, Nation States, and International Cooperation. 23 vols. New York and London: Routledge, 2011.

Hollifield, James F. Immigrants, Markets, and States: The Political Economy of Postwar Europe. Cambridge, MA: Harvard University Press, 1992.

Hollifield, James F. "Migration and International Relations: Cooperation and Control in the European Community." International Migration Review 26, no. 2 (1992): 568-595.

Hollifield, James F. "The Politics of International Migration: How Can We 'Bring the State Back In'?" In Migration Theory: Talking across Disciplines, edited by James F. Hollifield and Caroline F. Brettell, 2nd ed., 183-237. New York and London: Routledge, 2000.

Huysmans, Jef. "The European Union and the Securitization of Migration." JCMS. Journal of Common Market Studies 38, no. 5 (2000): 751-777.doi:10.1111/jcms.2000.38.issue-5.

İçduygu, Ahmet, and Damla B. Aksel. "Two-to-Tango in Migration Diplomacy: Negotiating Readmission Agreement Between the EU and Turkey." European Journal of Migration and Law 16, no. 3 (2014): 337-363.

Joffé, George. "Libya and the European Union: Shared Interests?" The Journal of North African Studies 16 , no. 2 (2011): 233-249.

Kapiszewski, Andrzej. Nationals and Expatriates: Population and Labour Dilemmas of the GulfCooperation Council States. Reading: Ithaca Press, 2001.

Keohane, Robert Owen, and Joseph S. Nye. "Power and Interdependence Revisited." International Organization 41, no. 4 (1987): 725-753. doi:10.1017/S0020818300027661.

Keohane, Robert Owen, and Joseph S. Nye. Power and Interdependence. 4th ed. London: Longman, 2012.

Klotz, Audie. "Migration After Apartheid: Deracialising South African Foreign Policy." Third World Quarterly 21, no. 5 (2000): 831-847.

Koinova, Maria. "Four Types of Diaspora Mobilization: Albanian Diaspora Activism For Kosovo Independence in the US and the UK." Foreign Policy Analysis 9, no. 4 (October 1, 2013): 433-453.

Koinova, Maria. "Sending States and Diaspora Positionality: Post-Conflict State-Building in Kosovo and Diasporas in Different Contexts," forthcoming.

Levitsky, Steven R., and Lucan A. Way. Competitive Authoritarianism: Hybrid Regimes After the Cold War. New York: Cambridge University Press, 2011.

Lutterbeck, Derek. "Migrants, Weapons and Oil: Europe and Libya After the Sanctions." The Journal of North African Studies 14, no. 2 (June 2009): 169-184.

Mack, Andrew. "Why Big Nations Lose Small Wars: The Politics of Asymmetric Conflict." World Politics 27, no. 2 (1975): 175-200.

Margheritis, Ana. Migration Governance Across Regions: State-Diaspora Relations in the Latin AmericaSouthern Europe Corridor. New York: Taylor \& Francis Limited, 2015.

Martin, Lisa L.“"Interests, Power, and Multilateralism." International Organization 46, no. 4 (1992): 765-792. Mellinger, Hillary, and Patrick van Berlo. "The Jordan Compact:Turning the Syrian Refugee Crisis into a Development Opportunity - Leiden Law Blog." 2016. https://leidenlawblog.nl/articles/the-jordancompact-turning-the-syrian-refugee-crisis.

Messina, Claire. "From Migrants to Refugees: Russian, Soviet and Post-Soviet Migration." International Journal of Refugee Law 6, no. 4 (1994): 620-635.

Miyashita, Akitoshi. Limits to Power: Asymmetric Dependence and Japanese Foreign Aid Policy. Oxford: Lexington Books, 2003.

Moravcsik, Andrew. The Choice for Europe: Social Purpose and State Power from Messina to Maastricht. Ithaca: Cornell University Press, 1998.

Natter, Katharina. Revolution and Political Transition in Tunisia: A Migration Game Changer? Migration Policy Institute, 2015. http://Www.Migrationpolicy.Org/Article/Revolution-and-Political-TransitionTunisiamigration-Game-Changer. 
Naujoks, Daniel. Migration, Citizenship, and Development: Diasporic Membership Policies and Overseas Indians in the United States. New Delhi: Oxford University Press, 2013.

Østergaard-Nielsen, Eva, ed. International Migration and Sending Countries: Perceptions, Policies and Transnational Relations. Houndmills: Palgrave Macmillan, 2003.

Oyen, M. The Diplomacy of Migration: Transnational Lives and the Making of US-Chinese Relations in the Cold War. The United States in the World. Ithaca: Cornell University Press, 2015.

Paoletti, Emanuela. "Migration and Foreign Policy: The Case of Libya." The Journal of North African Studies 16, no. 2 (June 2011): 215-231.

Paoletti, Emanuela. The Migration of Power and North-South Inequalities: The Case of Italy and Libya. New York: Springer, 2010.

Paul, Thazha Varkey. Asymmetric Conflicts: War Initiation by Weaker Powers. Cambridge: Cambridge University Press, 1994.

Pliez, Olivier. "Gros Plan : La Libye Sommée de Définir Une Politique Migratoire" [Libya Summoned to Define a Migration Policy.] Annuaire de l'Afrique Du Nord 41 (2003): 195-202.

Pliez, Olivier. "De L'immigration Au Transit? La Libye, Dans L'espace Migratoire Euro-Africain" [From Immigration to Transit? Libya in the Euro-African Migratory Space.] La Nouvelle Libye: Sociétés, Espaces Et Géopolitique Au Lendemain De L'embargo (2004): 139-158.

Rohen, Yehudit. Qaddafi's Libya in World Politics, 111. Boulder: Lynne Rienner, 2008.

Ronzitti, Natalino. “The Treaty on Friendship, Partnership and Cooperation Between Italy and Libya: New Prospects for Cooperation in the Mediterranean?" Bulletin of Italian Politics 1, no. 1 (2009): 125-133.

Sassen, Saskia. The Mobility of Labor and Capital: A Study in International Investment and Labor Flow. Cambridge: Cambridge University Press, 1988.

Soliman, Motazz A. "Libyan Foreign Policy from the Middle East to Africa: History, Transition and Implications." Maghreb Review: Majallat Al-Maghrib 30, no. 1 (2005): 73-97.

Squires, Nick. 2010. "Gaddafi: Europe Will ‘Turn Black' Unless EU Pays Libya £4bn a Year." The Telegraph, August 31. https://www.telegraph.co.uk/news/worldnews/africaandindianocean/libya/7973649/ Gaddafi-Europe-will-turn-black-unless-EU-pays-Libya-4bn-a-year.html.

Teitelbaum, Michael S. "Immigration, Refugees, and Foreign Policy." International Organization 38, no. 3 (July 1, 1984): 429-450.

Tempo, Carl J Bon. Americans at the Gate: The United States and Refugees During the Cold War. Princeton: Princeton University Press, 2008.

Thiollet, Helene. "Migration as Diplomacy: Labor Migrants, Refugees, and Arab Regional Politics in the Oil-Rich Countries." International Labor and Working-Class History 79, no. 1 (2011): 103-121.

Tsourapas, Gerasimos. "Notes from the Field: Researching Emigration in Post-2011 Egypt." American Political Science Association Migration \& Citizenship Newsletter 2, no. 2 (2014): 58-62.

Tsourapas, Gerasimos. "The Politics of Egyptian Migration to Libya." Middle East Research and Information Project (2015). https://www.merip.org/mero/mero031715.

Tsourapas, Gerasimos. "Why Do States Develop Multi-Tier Emigrant Policies? Evidence from Egypt." Journal of Ethnic and Migration Studies 41, no. 13 (November 10, 2015): 2192-2214.

Tsourapas, Gerasimos. "Nasser's Educators and Agitators across Al-Watan Al-'Arabi:Tracing the Foreign Policy Importance of Egyptian Regional Migration, 1952-1967." British Journal of Middle Eastern Studies 43, no. 3 (2016): 324-341. doi:10.1080/13530194.2015.1102708.

Tsourapas, Gerasimos. "Trump's Strategy on Immigration Comes Straight from the Middle East Playbook." The Conversation, January 31, 2017. https://theconversation.com/trumps-strategy-onimmigration-comes-straight-from-the-middle-east-playbook-72145?sg=301 dc758-c614-4e77b669-a56938767990\&sp=1\&sr=1.

Tsourapas, Gerasimos. "Labor Migrants as Political Leverage - Migration Interdependence and Coercion in the Mediterranean," forthcoming.

Tsourapas, Gerasimos. "Migration as Soft Power: Public Diplomacy and the International Dimension of Authoritarianism," forthcoming.

US Department Of State. "Background Note: Libya." (2004). https://2001-2009.state.gov/r/pa/ei/ bgn/5425.htm.

Van Evera, Stephen. Guide to Methods for Students of Political Science. Ithaca: Cornell University Press, 1997. 
Vandewalle, Dirk. A History of Modern Libya. 2nd ed. Cambridge: Cambridge University Press, 2012. Weiner, Myron, and Sharon Stanton Russell, eds. Demography and National Security. New York: Berghahn Books, 2001.

Zolberg, Aristide R. "The Next Waves: Migration Theory for a Changing World." The International Migration Review 23, no. 3 (1989): 403-430. 